\title{
REVIEW ESSAY: THE CAMPUS AND THE NEIGHBORLY COMMUNITY
}

\author{
Carmine Perrotti and Nicholas V. Longo
}

\section{Place-Based Community Engagement in Higher Education: A Strategy to Transform Universities and Communities}

\author{
Erica K. Yamamura and Kent Koth \\ Sterling, VA: Stylus Publishers, 2018
}

"Democracy must begin at home, and its home is the neighborly community," John Dewey (1927) wrote to describe the connections between local, face-to-face community building and the larger democratic project. Over the past few decades, the field of community engagement has developed around this vision throughout the landscape of higher education. With Place-Based Community Engagement in Higher Education: A Strategy to Transform Universities and Communities, Erica Yamamura and Kent Koth (2018) offer an innovative and unique framework for planning and pursuing engagement in the local neighborhoods where colleges and universities are located: namely, through what they term "place-based community engagement" (hereafter, PBCE).

PBCE is "a long-term university-wide commitment to partner with local residents, organizations, and other leaders to focus equally on campus and community impact within a clearly defined geographic area" (p. 18). A practical guide for community engagement practitioners and administrators, the book presents PBCE as "a promising strategy to respond to the changing context of higher education in order to more fully maximize university and community resources for deep and lasting social change” (p. 8). As such, the book is a welcome addition to the literature on higher education's community engagement efforts, offering lessons and insights from practitioners who are harnessing university resources for public purposes.

Through comparative case study analysis of a diverse set of institutions that have successfully employed PBCE, including Drexel University, Loyola University Maryland, San Diego State University, University of San Diego, and Seattle University, the authors offer a roadmap for how to move PBCE from theory to practice. Among the lessons from their study are five key principles that define best practices for PBCE: (a) a geographical focus, (b) equal emphasis on campus and community, (c) long-term vision and commitment, (d) university-wide engagement, and (e) drawing upon collective impact.

Given the emphasis on "a clearly defined geographic area” (p. 18), Yamamura and Koth acknowledge that 
PBCE will vary across “each institution's and community's unique cultural, historical, community, and organizational context” (p. 21). Thus, the book draws on specific examples and lessons arising from the diverse place-based campus cases. The results read as a sort of policy memo with trade-offs and concrete recommendations for the implementation of PBCE in varying contexts. Using document analysis, site visits, and interviews, the authors identify three distinct phases for the implementation of PBCE, including the exploration, development, and sustaining phases. They assert that institutions implementing PBCE move across a continuum of these (sometimes overlapping) phases. After an overview of the core aspects of each stage, the final chapters of the book explore PBCE from the perspective of community leaders; offer strategies for assessment and outcomes; and conclude with a discussion of lessons learned, challenges, and questions.

Throughout, the authors distinguish PBCE from other higher education community engagement strategies, such as service-learning pedagogy and anchor institutions-which sometimes feels like a distinction without a difference, especially with the latter. They do, however, convincingly argue that traditional higher education community engagement models have been more focused on student learning and campus goals above community impact. Place-Based Community Engagement in Higher Education invites colleges and universities to remake these priorities toward the local community. This reordering, as the authors argue, entails striving for campus-community partnerships that "place greater emphasis on mutual benefit" (p. 3).

Community impact continues to be the neglected aspect of service-learning and other community engagement efforts by colleges and universities. However, with a call for a laserlike focus on community, PBCE signals a step in the right direction. Calls for reciprocal relations and elevating community voices are not new but all too often demonstrate lofty rhetoric without subsequent practical application (Stoecker \& Tryon, 2009; White, 2012). As Byron White (2012) notes based on his PBCE-like work, colleges and universities "fall short of sharing full responsibility, accountability and authority for civic work with our community partners, especially marginalized citizens and residents of economically distressed communities” (p. 5). White offers a host of examples of the power imbalance, including failure to include community partners in grant proposals, programming decisions, survey and interview design, or even budgets.

Given these kinds of imbalances, Yamamura and Koth write that, "a place-based emphasis increases the likelihood for authentic and trusting campus-community partnerships to develop and expand in order to attain meaningful community engagement and campus impact” (p. 127). This shift helps re-imagine how colleges and universities might organize community engagement to make this configuration of priorities a reality. Especially compelling is the framing of these partnerships as a "50-50 proposition" (p. 129)—with the goal of focusing equally on campus and community impact. When campuses ask neighborhood residents about ways they would like to partner, a common request is more access to the campus, especially for youth (White, 2017). Thus, one key lesson learned from community partners was developing a "virtuous cycle" in which community members grow into roles as students and leaders in the university.

Through their chapter on community perspectives of PBCE, Yamamura and Koth highlight successes as well as challenges that community leaders have experienced through PBCE, including issues of racial and cultural differences between campuses and communities. Because the authors' study occurred at predominantly 
White institutions pursuing PBCE in Communities of Color, a lesson learned was that campus and community leaders implementing PBCE "must carefully navigate these differences to avoid perpetuating the very problems they are striving to solve" (p. 114). Rather than enter communities with a deficit lens through a "White saviorism" standpoint, institutions must develop partnerships that empower communities through an asset-based approach and provide professional development opportunities around race and culture for both students and faculty. In addition to calling for vigilance about racial and cultural differences between campuses and communities, the authors offer additional lessons learned from community partners, including the importance of trust, frequent communication and feedback loops, and being attentive to the roles and responsibilities of campus and community stakeholders.

While the shift toward community is welcome and needed, PBCE requires significant institutional change to be successful, including making epistemological and pedagogical changes that put community impact at the center of the teaching and research. Without this emphasis, campus-community partnerships will continue to be on the margins of higher education. As a short and focused primer on PBCE, the book omits much of the historical and theoretical understandings of this kind of change-making in higher education's broader community engagement efforts and how PBCE does or does not connect with these traditions (Hartley \& Saltmarsh, 2016). Thus, at times, the book reads as ahistorical and undertheorized, overlooking contributions of early adopters of PBCE such as John Dewey, Jane Addams, and Leonard Covello, and the work of campuses implementing place-based collaborations through university-assisted community schools, such as the University of Pennsylvania (Harkavy \& Longo, 2009; Benson et al., 2017).

Place-Based Community Engagement in Higher Education serves as an important catalyst in a conversation about place-based education and community impact. Perhaps most compelling and thought-provoking are the questions raised in the book for further exploration, where the authors identify future questions to further develop PBCE around topics such as how PBCE might look different in rural, minority-serving, or community colleges; whether a 50-50 proposition is aspirational or attainable; how issues of power, privilege, and racism might lead campuses to better connect community engagement with diversity and inclusion work; whether PBCE takes resources away from campus or expands the pool of resources; and what other partners might be invited to join PBCE's collective impact strategy.

If society is ultimately going to realize Dewey's democratic vision, we need for colleges and universities to take seriously a commitment to building neighborly communities. PBCE has much to add to this pursuit, especially in offering strategies for community impact. Place-Based Community Engagement in Higher Education helps set us off in the right direction to make this a reality.

\section{References}

Benson, L., Harkavy, I., Hartley, M., Hodges, R. A., Johnston, F. E., \& Weeks. J. (2017). Knowledge for social 
change: Bacon, Dewey, and the revolutionary transformation of research universities in the twenty-first century. Philadelphia, PA: Temple University Press.

Dewey, J. (1927). The public and its problems. New York, NY: Henry Holt.

Harkavy, I., \& Longo, N. (2009). Problem-solving with local communities: Using university-communityschool partnerships and place-based education to help revitalize urban America. Democracy and Education, $16(2), 16-23$.

Hartley, M., \& Saltmarsh, J. (2016). A brief history of a movement. In M. A. Post, E. Ward, N.

V. Longo, \& J. Saltmarsh (Eds.), Publicly engaged scholars: Next-generation engagement and the future of higher education (pp. 34-60). Sterling, VA: Stylus Publishing.

Stoecker, R., \& Tryon, E. A. (2009). Unheard voices: Community organizations and service learning. Philadelphia, PA: Temple University Press.

White, B. (2012). Confronting the careless university. Speech at American Democracy Project Conference (June), ejournal of Public Affairs. Retrieved at http://www.ejournalofpublicaffairs.org/1-2-confronting-thecareless-university/

White, B. (2017). Interview at Campus Compact Midwest Regional Conference at Loyola University in Chicago. Compact Nation.

\section{Authors}

CARMINE PERROTTI (perro054@umn.edu) is a doctoral candidate in the higher education program at the University of Minnesota. His research interests focus on the pedagogy, philosophy, and practice of servicelearning in higher education.

NICHOLAS V. LONGO (nlongo@providence.edu) is a Professor of Global Studies and Public and Community Service Studies at Providence College. His research focuses on civic education, community engagement, and publicly engaged scholarship including the forthcoming co-edited book, Creating Space for Democracy: A Primer on Dialogue and Deliberation in Higher Education (Stylus Publishing). 